\title{
PENGARUH RETURN ON EQUITY, RETURN ON ASSET, DAN NET \\ PROFIT MARGIN TERHADAP CAPITAL ADEQUACY RATIO \\ (Studi Empiris Pada Perusahaan Sektor Perbankan Konvensional yang Terdaftar di Bursa Efek Indonesia Periode Tahun 2015 - 2018)
}

\author{
NATRION, ST., SE., M.Ak \\ FILDA INACHA ZUKI \\ natribach@gmail.com, filda.inacha@gmail.com \\ Fakultas Ekonomi dan Bisnis - Program Studi Akuntansi \\ Universitas Satya Negara Indonesia
}

\begin{abstract}
The capital adequacy ratio used to measure the health of banks is the Capital Adequacy Ratio (CAR). The capital adequacy ratio can be measured from the capital ratio (capital), asset ratio (asset quality), management (management), earnings ratio (earnings), and liquidity ratio (liquidity). This study aims to determine whether Return On Equity, Return On Assets, and Net Profit Margins affect the Capital Adequacy Ratio in banking sector companies listed on the Indonesia Stock Exchange (BEI) for the 2015-2018 period.

The design used in this study is causal research, the method used is the literature study method and the documentation method while the type of data used in this study is secondary data and the population used is the banking sector and is listed on the Indonesia Stock Exchange for the period 2015-2018. The sampling method uses purposive sampling method. Based on predetermined criteria obtained by the number of company samples 28 companies for 4 years, so the total sample is 112. Hypothesis testing uses multiple linear regression analysis.

The results of the study partially prove that Return On Equity, Return On Assets significantly influence the Capital Adequacy Ratio. While Net Profit Margin does not affect the Capital Adequacy Ratio. The results of the study simultaneously prove that Return On Equity, Return On Assets, and Net Profit Margin affect the Capital Adequacy Ratio. With an adjusted $R$ square value of $50.4 \%$, which means the Capital Adequacy Ratio variable can be explained by the Return On Equity, Return On Asset and Net Profit Margin variables.
\end{abstract}

Keywords: Return On Equity (ROE), Return On Assets (ROA), Net Profit Margin (NPM), and Capital Adequacy Ratio (CAR).

Jurnal Ilmiah Akuntansi dan Ekonomi Volume. 6 Nomor. 1, Februari 2021 Hal. 91 


\section{PENDAHULUAN}

Bank Indonesia selaku bank sentral mempunyai peranan yang penting dalam penyehatan perbankan. Dalam menilai tingkat kesehatan bank, pada dasarnya Bank Indonesia menggunakan pendekatan kualitatif atas berbagai aspek yang berpengaruh terhadap kondisi suatu bank. Menurut Rivai, dkk (2013: 465) cara penilaian tingkat kesehatan bank mencakup komponen permodalan (capital), rasio asset (assets quality), manajemen (management), rasio laba (earning), dan rasio likuiditas (liquidity).

Kinerja perbankan yang baik tentu memberikan kepercayaan bagi nasabahnya dalam menempatkan dana yang dimilikinya dengan rasa aman. Kinerja perbankan dapat dilakukan dengan penilaian kesehatan bank. Penilaian kesehatan bank adalah penting untuk menilai bagaimana kondisi kesehatan bank itu sendiri, apakah dalam kondisi sehat atau tidak.

Rasio permodalan yang lazim digunakan untuk mengukur kesehatan bank adalah Capital Adequacy Ratio (CAR). CAR adalah rasio yang menunjukkan kemampuan bank dalam menyediakan dana atau modal untuk keperluan pengembangan usaha dan menanggung risiko kerugian dana yang disebabkan oleh aktivitas operasional bank (Sari, 2013). Menurut Febrianto dan Muid (2013), semakin tinggi nilai CAR maka menunjukkan semakin baiknya kemampuan finansial bank dalam mengantisipasi kerugian.

Return On Equity (ROE) merupakan rasio untuk mengukur kemampuan manajemen bank dalam mengelola modal yang ada untuk mendapatkan laba bersih (Kasmir, 2015). Return On Equity adalah rasio yang membandingkan antara laba setelah pajak dengan total modal sendiri (ekuitas). Rasio ini penting untuk mengetahui efektifitas dan efisiensi pengelolaan modal sendiri yang digunakan oleh manajemen perusahaan.

Return On Asset (ROA) menunjukkan kemampuan perusahaan dengan menggunakan seluruh aktiva yang dimiliki untuk menghasilkan laba setelah pajak. Semakin besar ROA, semakin efisien penggunaan aktiva perusahaan (Sudana, 2009). Return On Asset adalah rasio yang menunjukkan perbandingan antara laba sebelum pajak terhadap total aset yang dimiliki oleh bank. Rasio ini digunakan untuk mengukur kemampuan manajeman bank dalam memperoleh laba. Semakin besar ROA suatu bank, semakin besar pula tingkat keuntungan yang dicapai bank tersebut dan semakin baik pula posisi bank tersebut dari segi penggunaan aset.

Net Profit Margin (NPM) menunjukkan berapa besar persentase laba bersih yang diperoleh dari setiap penjualan. Semakin besar rasio ini, maka dianggap semakin baik kemampuan perusahaan untuk mendapatkan laba yang tinggi. Semakin besar NPM, maka kinerja perusahaan akan semakin produktif, sehingga akan meningkatkan kepercayaan investor untuk menanamkan modalnya pada perusahaan tersebut. Semakin tinggi NPM menunjukkan bank semakin efektif dalam penempatan aktiva produktif dalam bentuk kredit (Sugiyanto, 2002). Hasil penelitian menunjukkan bahwa NPM mampu digunakan sebagai indikator untuk memprediksi kesehatan bank. 


\section{Landasan Teori}

\section{a. Capital Adequacy Ratio}

CAR merupakan rasio permodalan yang menunjukkan kemampuan bank dalam menyediakan dana untuk keperluan pengembangan usaha dan menampung risiko kerugian dana yang diakibatkan oleh kegiatan operasi bank. CAR menunjukkan sejauh mana penurunan Asset bank masih dapat ditutup oleh Equity bank yang tersedia, semakin tinggi CAR semakin baik kondisi sebuah bank.

$$
\mathrm{CAR}=\frac{\text { Total Modal }}{A T M R} \times 100 \%
$$

\section{b. Return On Equity}

Return On Equity dalam analisis keuangan mempunyai arti yang sangat penting untuk mengukur kemampuan perusahaan dalam memperoleh laba. Dengan menggunakan Return On Equity, kemampuan bank dalam memperoleh laba tidak diukur menurut besar kecilnya jumlah laba yang dicapai, akan tetapi jumlah laba tersebut harus dibandingkan dengan jumlah dana yang telah digunakan dalam menghasilkan laba tersebut.Hasil pengembalian ekuitas atau Return on Equity atau rentabilitas modal sendiri merupakan rasio untuk mengukur laba bersih sesudah pajak dengan modal sendiri.

$$
\mathrm{ROE}=\frac{\text { Laba Setelah } \text { Pajak }}{\text { Ekuitas }} \times 100 \%
$$

\section{c. Return On Asset}

Return On Asset merupakan pengukuran kemampuan perusahaan secara keseluruhan dalam menghasilkan keuntungan dengan jumlah keseluruhan aktiva yang tersedia di dalam perusahaan, semakin tinggi Return On Asset berarti semakin baik keadaan suatu perusahaan dari segi penggunaan aset. Dengan menigkatnya keuntungan aset yang dimiliki maka besar pula tingkat keuntungan yang dicapai bank dan semakin baik pula posisi bank tersebut dalam penggunaan aset.

$$
\mathrm{ROA}=\frac{\text { Laba Sebelum Pajak }}{\text { Total Aset }} \times 100 \%
$$

\section{d. Net Profit Margin}

Net Profit Margin menunjukkan perbandingan antara laba bersih dengan penjualan (Hanafi dan Halim, 2005). Rasio ini digunakan untuk menghitung sejauh mana kemampuan bank yang bersangkutan dalam menghasilkan laba bersih (net income) ditinjau dari sudut operating incomenya .Semakin tinggi tingkat net profit margin rasio bank yang bersangkutan menunjukkan hasil yang semakin baik, demikian sebaliknya.

$$
\mathrm{NPM}=\frac{\text { Laba Bersih }}{\text { Total Pendapatan Operasional }} \times 100 \%
$$




\section{e. Kerangka Pemikiran}

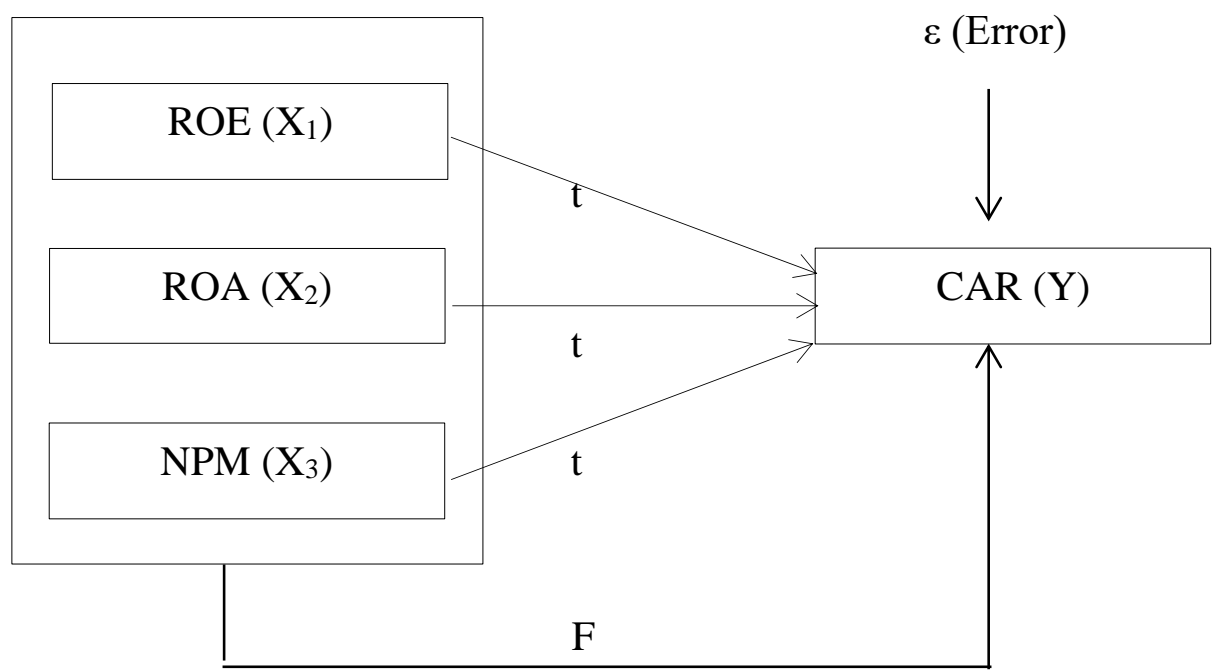

\section{Hubungan antara Return on Equity dengan Capital Adequacy Ratio}

Return on Equity merupakan salah satu ukuran profitabilitas yang menunjukkan tingkat pencapaian laba bersih terhadap modal sendiri yang digunakan oleh bank. Semakin tinggi ROE yang dicapai oleh bank menunjukkan laba bersih semakin tinggi, yang berarti kemungkinan akumulasi laba ditahan meningkat, sehingga modal sendiri akan meningkat dan CAR juga meningkat. $\mathrm{H}_{\mathrm{a} 1}$ :Diduga Return on Equity berpengaruh terhadap Capital Adequacy Ratio.

\section{Hubungan antara Return on Asset dengan Capital Adequacy Ratio}

Return on Asset merupakan pengukuran kemampuan perusahaan secara keseluruhan dalam menghasilkan keuntungan dengan jumlah keseluruhan aktiva yang tersedia di dalam perusahaan, semakin tinggi ROA berarti semakin baik keadaan suatu perusahaan dari segi penggunaan aset. Dengan meningkatnya keuntungan aset yang dimiliki maka besar pula tingkat keuntungan yang dicapai bank dan semakin baik pula posisi bank tersebut dalam penggunaan aset. Jika bank meraih keuntungan maka modalnya akan bertambah sehingga CAR meningkat. $\mathrm{H}_{\mathrm{a} 2}$ :Diduga Return on Asset berpengaruh terhadap Capital Adequacy Ratio.

\section{Hubungan antara Net Profit Margin dengan Capital Adequacy Ratio}

Net Profit Margin merupakan pengukuran kemampuan bank yang bersangkutan dalam menghasilkan laba bersih ditinjau dari sudut operating incomenya. NPM mengacu kepada pendapatan operasional bank terutama berasal dari kegiatan pemberian kredit yang dalam prakteknya memiliki berbagai risiko kredit. Semakin besar nilai NPM menunjukkan tingginya kemampuan perusahaan dalam menghasilkan laba bersih sehingga CAR meningkat.

$\mathrm{H}_{\mathrm{a} 3}$ :Diduga Net Profit Margin berpengaruh terhadap Capital Adequacy Ratio. 


\section{METODOLOGI PENELITIAN}

\section{a. Desain Penelitian}

Penelitian ini menggunakan penelitian kausal, yaitu untuk mengetahui pengaruh antara satu atau lebih variabel bebas terhadap variabel terikat. Dalam hal ini adalah pengaruh Return On Equity, Return On Asset, dan Net Profit Margin terhadap Capital Adequacy Ratio. Data yang digunakan dalam penelitian ini adalah data sekunder. Metode penggunaan yang digunakan dalam penelitian ini menggunakan dokumentasi. Metode dilakukan dengan cara mempelajari dokumen atau data-data yang dibutuhkan. Data yang dibutuhkan diambil melalui website Bursa Efek Indonesia www.idx.co.id.

\section{b. Populasi dan Sampel}

Populasi yang digunakan dalam penelitian ini adalah perusahaan sektor perbankan yang terdaftar di Bursa Efek Indonesia periode 2015-2018. Adapun kriteria yang digunakan dalam penelitian ini adalah sebagai berikut :

1) Bank umum yang terdaftar di BEI berturut-turut selama periode 2015-2018.

2) Perusahaan menerbitkan laporan keuangan selama 4 tahun berturut-turut periode 2015-2018.

3) Bank yang memperoleh laba selama periode penelitian.

\section{c. Metode Analisis Data}

Penelitian ini menggunakan analisis regresi linear berganda untuk pengujian hipotesis berikut :

$$
Y=\alpha+\beta_{1} X_{1}+\beta_{2} X_{2}+\beta_{3} X_{3}+\varepsilon
$$

Keterangan :

$$
\begin{array}{ll}
\mathrm{Y} & =\text { Capital Adequacy Ratio (CAR) } \\
\alpha & =\text { Konstanta } \\
\beta_{1-3} & =\text { Koefisien regresi } \\
\mathrm{X}_{1} & =\text { Return On Equity }(\mathrm{ROE}) \\
\mathrm{X}_{2} & =\text { Return On Asset }(\mathrm{ROA}) \\
\mathrm{X}_{3} & =\text { Net Profit Margin (NPM) } \\
\varepsilon & =\text { Error }
\end{array}
$$

\section{Hasil Penelitian dan Pembahasan}

Data penelitian ini adalah data sekunder berupa laporan keuangan dan laporan tahunan yang diperoleh melalui website www.idx.co.id dengan pemilihan sampel dengan metode purposive sampling. 
Tabel 4.1

Proses Pengambilan Sampel

\begin{tabular}{|c|l|c|}
\hline No. & \multicolumn{1}{|c|}{ Kriteria Pengambilan Keputusan } & Jumlah \\
\hline 1. & $\begin{array}{l}\text { Bank umum yang terdaftar di BEI berturut-turut selama } \\
\text { periode 2015-2018. }\end{array}$ & 40 \\
\hline 2. & $\begin{array}{l}\text { Perusahaan yang tidak menerbitkan laporan keuangan } \\
\text { selama 4 tahun berturut-turut periode 2015-2018. }\end{array}$ & - \\
\hline & $\begin{array}{l}\text { Bank yang tidak memperoleh laba selama periode } \\
\text { penelitian. }\end{array}$ & $(12)$ \\
\hline \multicolumn{2}{|l|}{ Jumlah sampel penelitian } & 28 \\
\hline \multicolumn{2}{|l|}{ Tahun Pengamatan } & 4 \\
\hline \multicolumn{2}{|l|}{ Total sampel penelitian } & 112 \\
\hline
\end{tabular}

Sumber : www.idx.co.id. Data diolah 2020

Berdasarkan kriteria yang telah ditetapkan dengan menggunakan metode purposive sampling, maka perusahaan perbankan yang terdaftar di Bursa Efek Indonesia yang memenuhi persyaratan sebanyak 28 perusahaan. Periode penelitian yang dilakukan adalah 4 tahun yaitu periode 2015 sampai dengan tahunn 2018 sehingga sampel penelitian ini berjumlah 112 sampel.

\section{a. Analisis Data}

Analisis statistik deskriptif ini dilakukan untuk menggambarkan suatu data yang dapat dilihat dari nilai masing-masing variabel penelitian. Berikut ini penulis sajikan tabel hasil statistik deskriptif.

Tabel 4.4 Descriptive Statistic

Hasil Uji Statistik Deskriptif (Setelah di Transformasi)

Descriptive Statistics

\begin{tabular}{lr|r|r|r|r} 
& N & Minimum & \multicolumn{1}{c}{ Maximum } & \multicolumn{1}{c}{ Mean } & \multicolumn{1}{c}{ Std. Deviation } \\
\hline LN_ROE & 112 &,- 67 & 3,40 & 2,1073 &, 78455 \\
\hline LN_ROA & 112 & $-2,41$ & 1,43 &, 3702 &, 76299 \\
\hline LN_NPM & 112 &, 58 & 3,71 & 2,8660 &, 65676 \\
\hline LN_CAR & 112 & 2,45 & 4,20 & 3,0530 &, 27298 \\
\hline Valid N (listwise) & 112 & & & & \\
\hline
\end{tabular}

Sumber : Hasil Output SPSS 24, data yang diolah,2020

Berikut penjelasan tabel statistik deskriptif atas masing-masing variabel :

1. Pada tabel 4.4 didapat nilai rata-rata (mean) dari Return On Equity sebesar 2,1073 artinya selama periode penelitian rata-rata bank yang dijadikan sampel memiliki nilai Return On Equity sebesar 2,10\%. Nilai minimum dari Return On Equity sebesar -0,67 artinya jumlah Return On Equity terendah yang diperoleh bank sebesar $-0,67 \%$ dan nilai maximum sebesar 3,40 artinya Return On Equity tertinggi yang dijadikan sampel memiliki nilai 
Return On Equity sebesar 3,40\%. Kemudian nilai standar deviasi sebesar 0,78455 .

2. Pada tabel 4.4 didapat nilai rata-rata (mean) dari Return On Asset sebesar 0,3702 artinya selama periode penelitian rata-rata bank yang dijadikan sampel memiliki nilai Return On Asset sebesar 0,37\%. Nilai minimum dari Return On Asset sebesar -2,41 artinya jumlah Return On Asset terendah yang diperoleh bank selama periode penelitian sebesar $-2,41 \%$ dan nilai maximum sebesar 1,43 artinya Return On Asset tertinggi yang diperoleh bank selama periode penelitan sebesar $1,43 \%$. Kemudian nilai standar deviasi sebesar 0,76299.

3. Pada tabel 4.4 didapat nilai rata-rata (mean) dari Net Profit Margin sebesar 2,8660 artinya selama periode penelitian rata-rata bank yang dijadikan sampel memiliki nilai Return On Asset sebesar 2,86\%. Nilai minimum dari Net Profit Margin sebesar 0,58 artinya jumlah Net Proft Margin terendah yang diperoleh bank selama periode penelitian sebesar $0,58 \%$ dan nilai maximum sebesar 3,71 artinya Net Profit Margin tertinggi yang diperoleh bank selama periode penelitan sebesar $3,71 \%$. Kemudian nilai standar deviasi sebesar 0,65676 .

4. Pada tabel 4.4 didapat nilai rata-rata (mean) dari Capital Adequacy Ratio sebesar 3,0530 artinya selama periode penelitian rata-rata bank yang dijadikan sampel memiliki nilai Capital Adequacy Ratio sebesar 3,05\%. Nilai minimum dari Capital Adequacy Ratio sebesar 2,45 artinya jumlah Capital Adequacy Ratio terendah yang diperoleh bank selama periode penelitian sebesar 2,45\% dan nilai maximum sebesar 4,20 artinya Capital Adequacy Ratio tertinggi yang diperoleh bank selama periode penelitan sebesar 4,20\%. Kemudian nilai standar deviasi sebesar 0,27298.

\section{b. Uji Asumsi Klasik}

Pengujian hipotesis pada penilitian ini menggunakan model regresi linear berganda. Untuk menggunakan model regresi linear berganda terlebih dahulu harus memenuhi uji asumsi klasik.

\section{1) Uji Normalitas}

\section{Tabel 4.5}

Hasil Uji One-Sample Kolmogrov-Smirnov Test One-Sample Kolmogorov-Smirnov Test

\begin{tabular}{llr} 
& & \multicolumn{1}{c}{$\begin{array}{r}\text { Unstandardized } \\
\text { Residual }\end{array}$} \\
\hline $\mathrm{N}$ & & 112 \\
\hline Normal Parameters & &, 0000000 \\
\cline { 2 - 3 } & Mean &, 18957426 \\
\cline { 2 - 3 } & Std. Deviation &, 072 \\
\cline { 2 - 3 } & Absolute &, 072 \\
\cline { 2 - 3 } & Positive &,- 053 \\
\cline { 2 - 3 } & Negative &, 072 \\
\hline Test Statistic & &, $200^{c, d}$ \\
\hline Asymp. Sig. (2-tailed) & & \\
\hline a. Test distribution is Normal. Differences & & \\
b. Calculated from data. & &
\end{tabular}


Berdasarkan hasil uji Kolmogrov-Smirnov di atas menunjukkan bahwa nilai K-S sebesar 0,072 dengan probabilitas signifikan sebesar 0,200>0,05 maka dapat disimpulkan bahwa data berdistribusi dengan normal.

\section{2) Uji Multikolinearitas}

Tabel 4.6

\begin{tabular}{|c|c|c|}
\hline \multicolumn{3}{|c|}{$\begin{array}{c}\text { Hasil Uji Multikolinearitas } \\
\text { Coefficients }^{\mathrm{a}}\end{array}$} \\
\hline \multirow[b]{2}{*}{ Model } & \multicolumn{2}{|c|}{ Collinearity Statistics } \\
\hline & Tolerance & VIF \\
\hline 1 (Constant) & & \\
\hline LN_ROE & ,263 & 3,808 \\
\hline LN_ROA & 233 & 4,288 \\
\hline LN_NPM & ,515 & 1,941 \\
\hline
\end{tabular}

Sumber : Hasil Output SPSS 24, data yang diolah,2020

Berdasarkan tabel 4.6 di atas terlihat bahwa besarnya nilai Tolerance pada variabel Return On Equity sebesar 0,263 ; Return On Asset 0,233 ; Net Profit Margin 0,515. Sedangkan besarnya nilai VIF pada variabel Return On Equity sebesar 3,808 ; Return On Equity 4,288 ; Net Profit Margin 1,941. Hasil dari perhitungan nilai tolerance dan VIF pada tabel diatas menunjukkan bahwa tidak ada variabel independen yang memiliki nilai tolerance kurang dari $10 \%$ yang berarti tidak ada korelasi antar variabel bebas yang nilainya lebih dari $95 \%$. Hasil perhitungan VIF juga dapat menunjukkan hal yang sama tidak ada satu variabel independen yang memiliki nilai VIF lebih dari 10\%. Maka dapat disimpulkan bahwa tidak ada multikolinearitas antar variabel independen dalam model regresi dan data yang di dapat dalam penelitian ini bebas dari masalah multikolinearitas. 


\section{3) Uji Heteroskedastisitas}

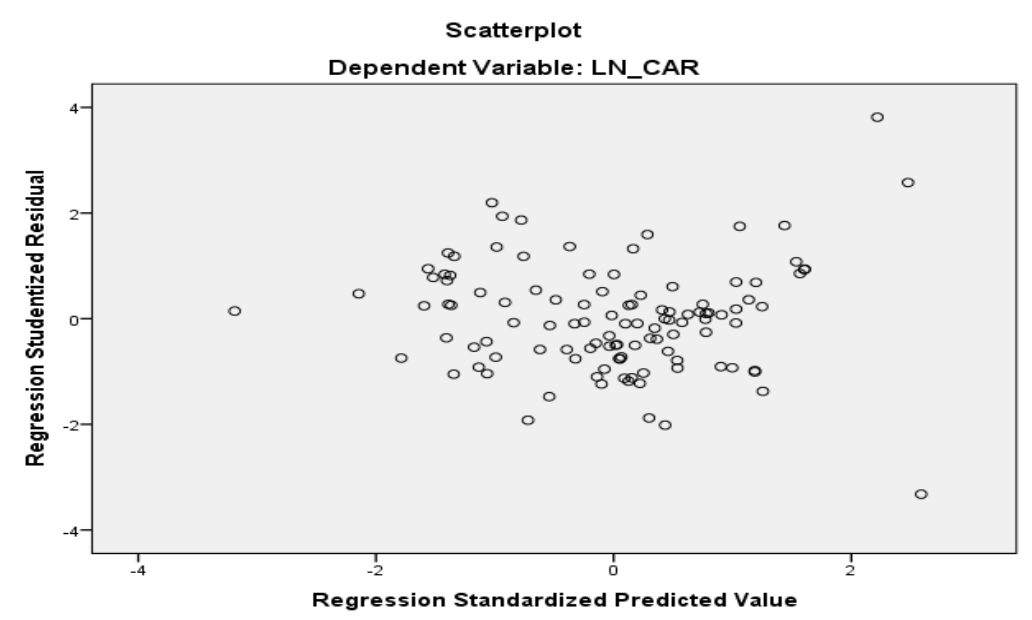

\section{Gambar 4.2}

Hasil Uji Heteroskedastisitas

Sumber : Hasil Output SPSS 24, data yang diolah,2020

Berdasarkan pada gambar scatterplot di atas bahwa dapat dilihat titik menyebar secara acak, tidak membentik sebuah pola tertentu yang jelas atau teratur, serta titik tersebahr di atas dan di bawah angka 0 pada sumbu Y. Dengan demikian dapat dikatakan bahwa tidak terjadi gejala heteroskedastisitas pada model regresi, sehingga model regresi layak digunakan untuk memprediksi pengaruh terhadap luas pengungkapan laporan tahunan.

\section{4) Uji Autokorelasi}

Tabel 4.7

Hasil Uji Autokorelasi

Model Summary ${ }^{\mathrm{b}}$

\begin{tabular}{lrr} 
Model & Std. Error of the Estimate & Durbin-Watson \\
\hline 1 &, 19219 &, 887 \\
\hline a. Predictors: (Constant), LN_NPM, LN_ROE, LN_ROA
\end{tabular}

Sumber : Hasil Output SPSS 24, data yang diolah,2020

Berdasarkan hasil uji autokorelasi pada tabel 4.7 di atas diketahui bahwa nilai Durbin Watson (DW) sebesar 0,887 dengan tingkat signifikansi sebesar 0,05 (5\%); $\mathrm{k}=3$ dan sampel sebanyak 112. Dalam tabel DW diperoleh nilai batas atas (dU) sebesar 1,7472 dan nilai batas bawah (dL) sebesar 1,6373. Dengan demikian nilai tersebut berada dalam kriteria $0<\mathrm{DW}<\mathrm{dL}$ yaitu $(0<0,887<1,6373)$ maka model regresi yang digunakan pada penelitian ini tidak terdapat masalah autokorelasi. 


\section{c. Analisis Regresi Linear Berganda}

Tabel 4.8

Hasil Uji Regresi Linear Berganda

Coefficients $^{\mathbf{a}}$

\begin{tabular}{lr|r|r|r|r}
\multicolumn{7}{c}{} & \multicolumn{7}{c|}{$\begin{array}{l}\text { Unstandardized Coefficients } \\
\text { Model }\end{array}$} & \multicolumn{1}{c}{ Standardized Coefficients } & & \\
\hline 1 & S & Std. Error & Beta & t & Sig. \\
\hline (Constant) & 3,698 &, 123 & & 29,963 &, 000 \\
\hline LN_ROE &,- 473 &, 045 & $-1,360$ & $-10,426$ &, 000 \\
\hline LN_ROA &, 441 &, 050 & 1,233 & 8,913 &, 000 \\
\hline LN_NPM &, 066 &, 039 &, 158 & 1,698 &, 092 \\
\hline
\end{tabular}

a. Dependent Variable: LN_CAR

Sumber : Hasil Output SPSS 24, data yang diolah,2020

Dari tabel di atas diperoleh persamaan regresi sebagai berikut :

$\mathrm{Y}=3,698-0,473 \mathrm{X} 1+0,441 \mathrm{X} 2+0,66 \mathrm{X} 3+\epsilon$

Berdasarkan persamaan regresi tersebut, maka dapat diartikan sebagai berikut :

a) Nilai konstanta adalah 3,698 artinya apabila variabel Return On Equity, Return On Asset, dan Net Profit Margin bernilai nol (tidak ada) maka Capital Adequacy Ratio akan bernilai 3,698.

b) Nilai koefisien Return On Equity adalah -0,473 artinya setiap kenaikan Return On Equity sebesar satu-satuan, maka Capital Adequacy Ratio akan turun sebesar 0,473.

c) Nilai koefisien Return On Asset adalah 0,441 artinya setiap kenaikan Return On Asset sebesar satu-satuan, maka Capital Adequacy Ratio meningkat sebesar 0,441 .

d) Nilai koefisien Net Profit Margin adalah 0,66 artinya setiap kenaikan Net Profit Margin sebesar satu-satuan, maka Capital Adequacy Ratio meningkat sebesar 0,66.

\section{d. Uji Hipotesis}

1) Uji t

Tabel 4.9

Hasil Uji $t$

Coefficients $^{\mathrm{a}}$

\begin{tabular}{|c|c|c|c|c|c|}
\hline \multirow[b]{3}{*}{ Model } & & \multirow[b]{3}{*}{$\mathrm{t}$} & \multirow[b]{3}{*}{ Sig. } \\
\hline & \multicolumn{2}{|c|}{ Unstandardized Coefficients } & \multirow{2}{*}{$\begin{array}{c}\text { Standardized Coefficients } \\
\text { Beta }\end{array}$} & & \\
\hline & $\mathrm{B}$ & Std. Error & & & \\
\hline 1 (Constant) & 3,698 &, 123 & & 29,963 &, 000 \\
\hline LN_ROE &,- 473 & 045 & $-1,360$ & $-10,426$ &, 000 \\
\hline LN_ROA & ,441 &, 050 & 1,233 & 8,913 &, 000 \\
\hline LN_NPM &, 066 & 039 &, 158 & 1,698 & ,092 \\
\hline
\end{tabular}

a. Dependent Variable: LN_CAR 
Sumber : Hasil Output SPSS 24, data yang diolah,2020

Berdasarkan tabel di atas hasil uji t adalah sebagai berikut :

a) Variabel Return On Equity (ROE)

Berdasarkan tabel 4.9 di atas di dapat nilai $t_{\text {hitung }}(-10,426)>t_{\text {tabel }}$ $(1,98217)$ dan nilai signifikansi (Sig) sebesar 0,000 $<0,05$, maka $\mathrm{H}_{01}$ ditolak dan $\mathrm{H}_{\mathrm{a} 1}$ diterima. Yang berarti variabel Return On Equity berpengaruh signifikan terhadap Capital Adequacy Ratio.

a) Variabel Return On Asset (ROA)

Berdasarkan tabel 4.9 di atas di dapat nilai $t_{h i t u n g}(8,913)>t_{\text {tabel }}$ $(1,98217)$ dan nilai signifikansi (Sig) sebesar $0,000<0,05$, maka $\mathrm{H}_{\mathrm{o} 2}$ ditolak dan $\mathrm{H}_{\mathrm{a} 2}$ diterima. Yang berarti variabel Return On Asset berpengaruh signifikan terhadap Capital Adequacy Ratio.

b) Variabel Net Profit Margin (NPM)

Berdasarkan tabel 4.9 diatas di dapat nilai $t_{\text {hitung }}(1,698)<t_{\text {tabel }}(1,98217)$ dan nilai signifikansi (Sig) sebesar 0,092 >0,05, maka $\mathrm{H}_{\mathrm{o}}$ diterima dan $\mathrm{H}_{\mathrm{a} 3}$ ditolak. Yang berarti variabel Net Profit Margin tidak berpengaruh terhadap Capital Adequacy Ratio.

\section{2) Uji F}

\section{Tabel 4.10}

Hasil Uji F

ANOVA $^{\mathrm{a}}$

\begin{tabular}{|c|c|c|c|c|c|c|}
\hline \multicolumn{7}{|c|}{ ANOVA $^{a}$} \\
\hline Model & & Sum of Squares & df & Mean Square & $\mathrm{F}$ & Sig. \\
\hline \multirow[t]{3}{*}{1} & Regression & 4,282 & 3 & 1,427 & 38,647 &, $000^{\mathrm{b}}$ \\
\hline & Residual & 3,989 & 108 & ,037 & & \\
\hline & Total & 8,272 & 111 & & & \\
\hline
\end{tabular}

a. Dependent Variable: LN_CAR

b. Predictors: (Constant), LN_NPM, LN_ROE, LN_ROA

Sumber : Hasil Output SPSS 24, data yang diolah,2020

Berdasarkan hasil uji $\mathrm{F}$ dari tabel 4.10 di atas diketahui $\mathrm{F}_{\text {hitung }}$ $(38,647)>F_{\text {tabel }}(2,69)$ dan nilai signifikan $0,000<0,05$ maka $\mathrm{H}_{04}$ ditolak dan $\mathrm{H}_{\mathrm{a} 4}$ diterima. Hal ini berarti bahwa ada pengaruh secara simultan antara variabel Return On Equity, Return On Asset, dan Net Profit Margin terhadap variabel Capital Adequacy Ratio.

\section{3) Uji Koefisien Determinasi $\left(\mathbf{R}^{2}\right)$}

\begin{tabular}{|c|c|c|c|}
\hline \multirow{2}{*}{\multicolumn{4}{|c|}{$\begin{array}{c}\text { Tabel } 4.11 \\
\begin{array}{c}\text { Hasil Uji Koefisien Determinasi }\left(\mathbf{R}^{2}\right) \\
\text { Model Summary }\end{array}\end{array}$}} \\
\hline & & & \\
\hline Model & $\mathrm{R}$ & R Square & Adjusted R Square \\
\hline 1 &, $720^{\mathrm{a}}$ &, 518 &, 504 \\
\hline
\end{tabular}


Sumber : Hasil Output SPSS 24, data yang diolah,2020

Berdasarkan tabel 4.11 di atas diketahui bahwa nilai adjusted $R$ square sebesar 0,504 (50,4\%). Hal ini berarti 50,4\% variabel Capital Adequacy Ratio dapat dijelaskan oleh variabel Return On Equity, Return On Asset, dan Net Profit Margin. Sedangkan sisanya 49,6\% dijelaskan oleh faktor lain seperti Loan To Deposit Ratio, Non Performing Loan, Biaya Operasional Terhadap Pendapatan Operasional, dan lain-lain yang tidak disertakan dalam variabel penelitian ini.

\section{Kesimpulan dan Saran}

\section{a. Kesimpulan}

Berdasarkan hasil penelitian ini yang mengenai tentang pengaruh Return On Equity, Return On Asset, dan Net Profit Margin terhadap Capital Adequacy Ratio pada perusahaan perbankan yang terdaftar di Bursa Efek Indonesia (BEI) periode 2015-2018, maka dapat diambil kesimpulan sebagai berikut :

a) Variabel Return On Equity (X1) berpengaruh signifikan terhadap Capital Adequacy Ratio (Y). Hal ini dapat dilihat dari nilai $t_{\text {hitung }}(-$ $10,426)>t_{\text {tabel }}(1,98217)$ dan tingkat signifikan sebesar $0,000<0,05$, maka $\mathrm{H}_{\mathrm{o} 1}$ ditolak dan $\mathrm{H}_{\mathrm{a} 1}$ diterima.

b) Variabel Return On Asset (X2) berpengaruh signifikan terhadap Capital Adequacy Ratio (Y). Hal ini dapat dilihat dari nilai $t_{\text {hitung }}(8,913)>t_{\text {tabel }}$ $(1,98217)$ dan tingkat signifikasn sebesar $0,000<0,05$, maka $\mathrm{H}_{\mathrm{O} 2}$ ditolak dan $\mathrm{H}_{\mathrm{a} 2}$ diterima.

c) Variabel Net Profit Margi (X3) tidak berpengaruh terhadap Capital Adequacy Ratio (Y). Hal ini dapat dilihat dari nilai thitung $(1,698)<$ $\mathrm{t}_{\text {tabel }}(1,98217)$ dan tingkat signifikan sebesar 0,092 >0,05, maka $\mathrm{H}_{03}$ diterima dan $\mathrm{H}_{\mathrm{a} 4}$ ditolak.

d) Variabel Return On Equity(X1), Return On Asset(X2) dan Net Profit $\operatorname{Margin}(\mathrm{X} 3)$ berpengaruh secara signifikan terhadap Capital Adequacy Ratio (Y). Hal ini dapat dilihat dari nilai $F_{\text {hitung }}(38,647)<F_{\text {tabel }}(2,69)$ dan nilai signifikan $0,000<0,05$, maka $\mathrm{H}_{04}$ ditolak dan $\mathrm{H}_{\mathrm{a} 4}$ diterima. Dengan nilai adjusted $R$ square sebesar 0,504 (50,4\%). Hal ini berarti 50,4\% varibel Capital Adequacy Ratio dapat dijelaskan oleh variabel Return On Equity, Return On Asset, dan Net Profit Margin. Sedangkan sisanya 49,6\% dijelaskan oleh faktor lain yang tidak disertakan dalam variabel penelitian ini. 


\section{b. Saran}

Berdasarkan hasil dari pembahasan penelitian dan kesimpulan diatas, adapun beberapa saran yang dapat diberikan dalam penelitian adalah sebagai berikut :

1) Penelitian selanjutnya diharapkan mengembangkan variabel-variabel lain yang dapat berhubungan dengan struktur modal agar dapat memberikan gambaran yang lebih luas mengenai faktor apa saja yang mempengaruhi Capital Adequacy Ratio, dapat menambahkan periode penelitian yang lebih panjang agar menemukan hasil yang lebih baik, dan dapat menggunakan sampel yang lebih banyak dengan karakteristik yang lebih beragam.

2) Para calon investor dapat mengetahui atau mempertimbangkan pengaruh ROE, ROA dan NPM terhadap CAR sebelum memberikan investasinya kepada perusahaan.

\section{DAFTAR PUSTAKA}

Adnan, Ridwan, F. Pengaruh Ukuran Bank, Dana Pihak Ketiga, Capital Adequacy Ratio, dan Loan To Deposit Ratio Terhadap Penyaluran Kredit Pada Perusahaan Perbankan yang Terdaftar Di Bursa Efek Indonesia Tahun 2011-2015, Universitas Syiah Kuala, 2016.

Ahmad Rodoni, dan Herni Ali. Manajemen Keuangan, Yogyakarta, BPFE, 2010.

Benny Agus Setiono. Pengaruh Return On Asset (ROA) dan Return On Equity (ROE) terhadap Capital Adequacy Ratio (CAR) Sektor Perbankan yang Terdaftar di Bursa Efek Indonesia, Universitas Hang Tuah Surabaya, 2017.

Brigham,E.F, dan Gapenski. Fundamentals of Financial Management, Jakarta, Erlangga, 1997.

Dendawijaya, Lukman. Manajemen Perbankan, Edisi kedua, Jakarta, Ghalia Indonesia, 2005.

Dessy. Analisis Tingkat Kesehatan Bank Dengan Metode Risk Profile, Good Corporate Governance, Earning And Capital (RGEC) Pada BPD Se Indonesia Periode 2015-2017, Universtas Sam Ratulangi, 2019.

Enny Evelina, Pengaruh Rasio Profitabilitas Terhadap Kesehatan Permodalan Bank Swasta Nasional di BEI, UNIKA WIDYA MANDALA, 2012.

Fahmi, Irfan. Analisis Laporan Keuangan, Bandung, Alfabeta.2011

Febrianto, Dwi \& Dul Muid. Analisis Pengaruh Dana Pihak Ketiga, LDR, NPL, CAR, ROA, dan BOPO terhadap Jumlah Penyaluran Kredit (Studi pada Bank Umum yang Terdaftardi Bursa Efek Indonesia), Diponegoro Journal of Accounting, 2(4):1-11. 
Ghozali, Imam. Analisis Multivarative Dengan Program SPSS, Edisi ke tujuh, Semarang, Badan Penerbit Universitas Diponegoro, 2013.

Hanafi, Halim. Analisis Laporan Keuangan, Yogyakarta, Unit Penerbit dan Percetakan AMP-YKPN, 2005.

Hanafi, Halim. Analisis Laporan Keuangan, Edisi Ketiga, Cetakan Pertama, Yogyakarta, Penerbit UPP Sekolah Tinggi Ilmu Manajemen 2012.

Herman Darmawi. Manajemen Perbankan, Cetakan Kedua, Jakarta, Remaja Rosdakarya, 2012.

Hery. Analisis Laporan Keuangan Integrated And Comprehensive Edition, Jakarta, PT Gramedia. 2016.

Ikatan Bankir Indonesia. Memahami Bisnis Bank, Edisi Pertama, Jakarta, PT Gramedia Pustaka Utama, 2013.

Kasmir. Pengantar Manajemen Keuangan, Jakarta, Prenada Media, 2010.

Kasmir. Dasar-dasar Perbankan, Jakarta, PT.Raja Grafindo, 2007.

Kasmir. Bank dan Lembaga Keuangan Lainnya, Jakarta, PT.Raja Grafindo. 2008.

Marissa, Susi. Analisis Perbandingan Tingkat Kesehatan Bank dengan Menggunakan Pendekata RGEC Studi pada PT.Mandiri (Persero), Tbk dan Bank Negara Indonesia (Persero), Tbk Periode 2014-2018, Universitas Batanghari Jambi, 2019.

Muhammad. Bank Syariah Problem dan Proses Perkembangan di Indonesia, Yogyakarta, Graha Ilmu, 2005.

Peraturan Bank Indonesia. Kewajiban Penyediaan Modal Minimum Bank Umum Nomor : 15/12/PBI/2013, 2013.

Prasetya Adi Pratama. Pengaruh NIM, NPL, ROA, LDR DAN BOPO Terhadap Capital Adequacy Ratio Studi Empiris Pada Perusahaan Sub Sektor Perbankan yang Terdaftar Di Bursa Efek Indonesia Periode 2013-2017, Universitas Islam Negeri Syarif Hidayatullah Jakarta, 2018.

Samsul.H.P, dan M.H.Romi. Pengaruh Paket Regulasi Perbankan 1998 Terhadap Kehati-hatian Sektor Perbankan di Indonesia, Analisis Terhadap Capital Adequacy Ratio (CAR), Telaah Bisnis, Vol.2, No.2, Hal:83-97 
Siska Fitriani. Pengaruh ROA, ROE, FDR, BOPO DAN INFLASI Terhadap Kecukupan Modal Pada Bank Umum Syariah Di Indonesia, Universitas Islam Negeri Syarif Hidayatullah Jakarta,2016.

Sugiyanto,F.X. Manfaat Indikator-Indikator Keuangan Dalam Pembentukan Model Prediksi Kondisi Kesehatan Perbankan, Jurnal Bisnis Strategi, Vol.10 Hal: 11-23.

Wijaya,S.p. Pengaruh Intelektual Capital Terhadap Profitabilitas Pada Perusahaan Farmasi yang Terdaftar di Bursa Efek Indonesia Periode 20062010, Skripsi, Fakultas Ekonomi Universitas Katolik Widya Mandala, Surabaya, 2012.

Www.idx.co.id

http://antohilya.blogspot.com/2011/11/normal-0-false-false-false-in-x-none-

$\underline{\mathrm{x} . \mathrm{html}}$

https://dosen.perbanas.id/car-capital-adequacy-ratio/

https://www.simulasikredit.com/apa-itu-return-on-equity-roe/

https://www.edusaham.com/2019/04/pengertian-return-on-asset-roa.html

http://www.sahamgain.com/2018/04/analisis-fundamental-perbedaan-rasio.html 